\title{
Combined Multifactor Evidence of a Giant Lower-Mantle Ring Structure below the Eastern Mediterranean
}

\author{
Lev Eppelbaum 1 ${ }^{*}$ Zvi Ben-Avraham¹, Youri Katz², Sierd Cloetingh³, Mikhail Kaban ${ }^{4,5}$ \\ ${ }^{1}$ Department of Geosciences, Faculty of Exact Sciences, Tel Aviv University, Ramat Aviv, Tel Aviv, Israel \\ ${ }^{2}$ Steinhardt Museum of Natural History \& National Research Center, Faculty of Life Sciences, Tel Aviv University, Ramat Aviv, \\ Tel Aviv, Israel \\ ${ }^{3}$ Faculty of Geosciences, Utrecht University, TA Utrecht, The Netherlands \\ ${ }^{4}$ Helmholtz-Centre Potsdam, GFZ German Research Centre for Geosciences, Telegrafenberg, Potsdam, Germany \\ ${ }^{5}$ Schmidt Institute of Physics of the Earth, RAS, Moscow, Russia \\ Email: *levap@post.tau.ac.il, levap@tauex.tau.ac.il
}

How to cite this paper: Eppelbaum, L., Ben-Avraham, Z., Katz, Y., Cloetingh, S. and Kaban, M. (2020) Combined Multifactor Evidence of a Giant Lower-Mantle Ring Structure below the Eastern Mediterranean. Positioning, 11, 11-32.

https://doi.org/10.4236/pos.2020.112002

Received: March 17, 2020

Accepted: April 5, 2020

Published: April 8, 2020

Copyright (C) 2020 by author(s) and Scientific Research Publishing Inc. This work is licensed under the Creative Commons Attribution International License (CC BY 4.0).

http://creativecommons.org/licenses/by/4.0/ Open Access

\begin{abstract}
In the Arabian-Northern African region, interaction of the Nubian, Arabian and Eurasian plates and many small tectonic units is conspicuous. In order to better understand this interaction, we use satellite derived gravity data (retracked to the Earth's surface) recognized now as a powerful tool for tectono-geodynamic zonation. We applied the polynomial approximation to the gravity data which indicated the presence of a large, deep ring structure in the eastern Mediterranean centered below the Island of Cyprus. Quantitative analysis of residual gravity anomaly provides an estimate of the deep anomalous body's upper edge at a depth of about $1700 \mathrm{~km}$. Computations of the residual gravity anomalies for the lower mantle also indicate presence of anomalous sources. The GPS vector pattern coinciding with the gravity trend implies counter clockwise rotation of this structure. Independent analyses of the geoid isolines map and seismic tomography data support the existence of a deep anomaly. Paleomagnetic data analysis from the surrounding regions confirms a counter clockwise rotation. Numerous petrological, mineralogical, geodynamical and tectonic data suggest a relation between this deep structure and near-surface processes. This anomaly sheds light on a number of phenomena including the Cyprus gravity anomaly, counter clockwise rotation of the Mesozoic terrane belt and asymmetry of basins along continental transform faults.
\end{abstract}

\section{Keywords}

Satellite Gravity, Geodynamics, Tectonics, Paleomagnetism, GPS, Integrated 
Analysis

\section{Introduction}

Understanding the relationship between deep geodynamics and subsurface geological processes is one of the prime challenges in Solid Earth Sciences [1] [2]. Here we present a combined analysis of the northern Africa-eastern Mediterranean area, where large tectonic plates (Nubian, Arabian and Eurasian) and a number of comparatively small tectonic plates interact [3]. This $\sim 24$ million $\mathrm{km}^{2}$ region (Figure 1) includes active rifts and collision belts, a complex pattern of continental and oceanic crusts of different ages, intense seismic activity, as well as several high-amplitude gravity anomalies and seismic velocity anomalies observed at great depths. In this region, zones of the final phases of subduction and the initial stages of rifting (spreading) are comparatively closely located (e.g., [4] [5] [6] [7] [8]). The region is located in the junction zone between East Gondwana and Eurasia, the geological-geophysical instability of which is determined by the intensity of geodynamics - both collisional and rift spreading. Here, different folded belts and cratons are developed and a variety of geological and geophysical processes are manifested (e.g., [3] [7] [9]). The eastern Mediterranean is a tectonically complex region evolving in the midst of the progressive Afro-Eurasian collision.

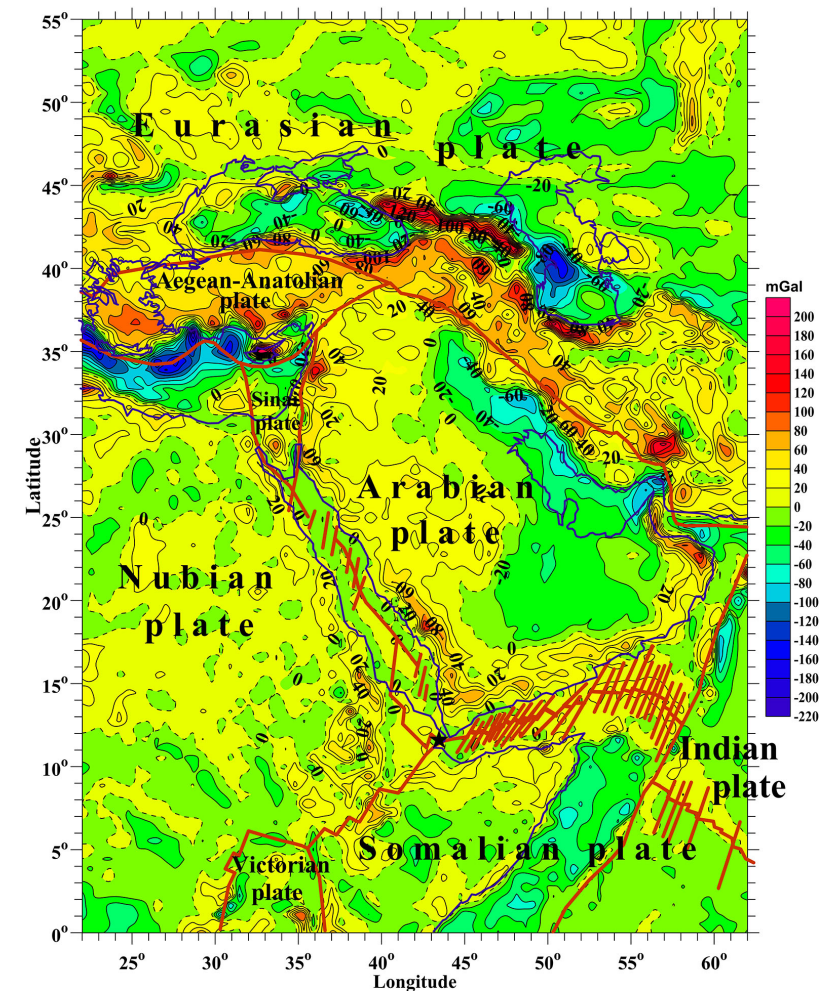

Figure 1. Satellite derived gravity map supported by main tectonic elements. Blue lines show boundaries between seas and land, and bold red lines indicate key tectonic faults. 
The combination of these geological-geophysical elements requires a structural-geodynamic analysis using modern methodological and numerical methods. Geophysical surveys of the eastern Mediterranean have indicated an extensive zone of development of thinned continental crust [2] and identified a chain of pre-Alpine terranes in this region [4] [10]. Of these geological and geophysical features, the most striking and least well understood is the Cyprus anomaly-one of the highest-amplitude gravity anomalies in the world (about 200 mGals in the Bouguer reduction) [11]. In this paper, we present a combined analysis of a number of significant geophysical and geological factors that shed light on the deep structure of the studied region.

Main outlines of the article's sections are presented below.

Section 2 displays application of the polynomial approximation to satellite derived gravity data and quantitative interpretation of the residual anomaly; computation of residual gravity anomalies from the lower mantle (based mainly on seismic data) confirms generally existence of anomalous object.

Brief analysis of geoid isolines map and its relationship with the deep anomalous structure is presented in Section 3.

Combined analysis of the main available geological and geophysical factors underlying presence of the giant deep rotating structure is shown in Section 4.

Section 5 is suggested to integrated examination of the numerous geological and geodynamic (both local and regional) features of the deep ring-like object; separately its influence to some modern geological-geophysical phenomena is discussed.

\section{Examination of Satellite Derived Gravity Data}

Regional gravity observations (shipborne and airborne) in the pre-satellite epoch are not uniform, containing large "white spots" resulting from variations in different scales, as well as differences in the accuracies and methodologies of gravity field observations and processing. In addition, most of the available shipborne and airborne gravity data are studied with errors in their gravity field computations exceeding 2 - $3 \mathrm{mGals}$ and up to $5 \mathrm{mGals}$. Modern satellite gravimetric data are a powerful and effective tool for regional tectono-geodynamic zonation including data segmentation, transformation, and comprehensive tectono-structural interpretation [12]-[17]. The satellite gravity data for this study were obtained from the World Gravity DB as retracked from Geosat and ERS missions [18]. For the gravity map construction depicted in Figure 1, more than $9.5 \times 10^{6}$ satellite gravity observations were compiled. These observations were made with regular global 1-minute grids, where the error of gravity data computation (retracked to marine/land surface) was estimated at $1-1.2 \mathrm{mGals}$. Examination of satellite data within the context of a tectonic regional analysis in many cases enables to detect influences on crustal structure and thickness of lithosphere (e.g., [14] [16]).

Eppelbaum and Katz [15] have shown that for investigation of deep structure in large regions (many million $\mathrm{km}^{2}$ ) the satellite observed and retracked to the 
Earth's surface gravity data may be employed without any additional reductions. Initially the studied Arabian-Northern African region was limited by the coordinates of $0-38^{\circ} \mathrm{N}$ and $30-57^{\circ} \mathrm{W}$ [15] [16]. In the both aforementioned works various peculiarities of the earth's crust and lithosphere were analyzed. However, in these works consistent relationships between the regional counterclockwise GPS pattern (e.g., [6] [19]) and the lithosphere's structure were not found. Therefore, it was concluded that the main source causing the GPS outline may occur at large depths.

In the present investigation the investigated area is extended to $0-55^{\circ} \mathrm{N}$ and $22-62^{\circ} \mathrm{W}$. For the satellite gravity set analysis were applied several reliable mathematical tools including polynomial approximation and some other procedures.

\subsection{Polynomial Approximation}

To better resolve the nature of these anomalies, we implement the polynomial approximation, a powerful instrument for solving a range of problems in mathematics and applied sciences (e.g., [20] [21]). Polynomial computation identifies generalized trends in datasets. Processing of the aforementioned satellite gravity set ("big data") practically eliminates the appearance of random main components that can lead to errors in smaller datasets.

The general trend obtained from the polynomial cubic surface $\left(A+B x+C y+D x^{2}+E x y+F y^{2}+G x^{3}+H x^{2}+I x^{2}+J y\right) \quad$ (Figure 2) (residual anomaly) is similar to results that were obtained by distance weighting and nonlinear filtering. The main trend in all these processed gravity maps reflects a deep oval (quasi-ring) structure superficially reflecting a deep source of this anomaly. It should be noted that a comparable trend is reflected in a free air gravity map of long wavelength (800 - $3500 \mathrm{~km}$ ) anomalies [22].

\subsection{Quantitative Analysis of the Residual Gravity Anomaly}

It is conventional practice to interpret residual potential field anomalies quantitatively (e.g., [23] [24]). As it is well known, depth of anomalous source is associated with the wide of anomaly, inclination of its branches, square occupied by anomaly area and some other parameters. A preliminary analysis of the obtained gravity anomaly was carried out using improved tangent, characteristic point and areal methods developed to examine potential geophysical anomalies in conditions where the level of the normal field is unknown [25]. These methods suggested that an upper edge of the giant deep ring structure (GDRS) occurs at a depth of about $1700 \mathrm{~km}$, indicating that the anomalous source is in the lower mantle. We will designate a projection of the GDRS to the upper geological sections (lithosphere and near-surface) as GDRSP.

\subsection{Computations of Residual Gravity Anomalies for the Lower Mantle}

To test the abovementioned hypothesis, computations of residual gravity 


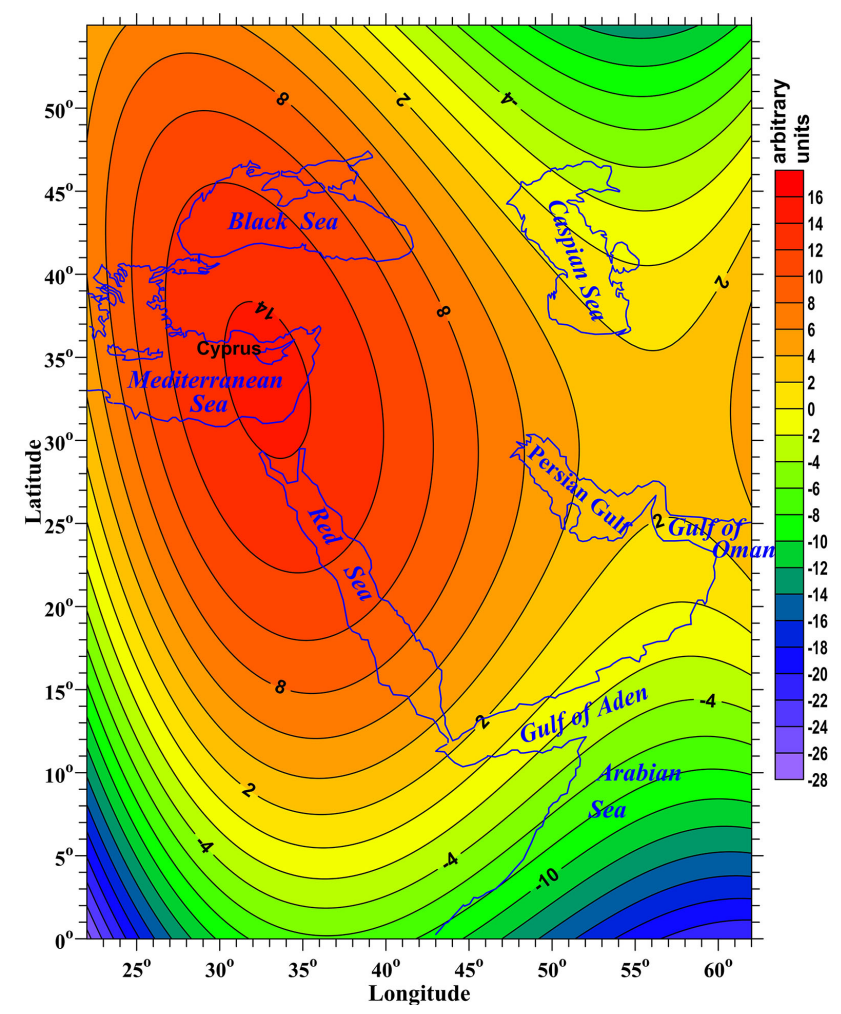

Figure 2. Results of the cubic polynomial approximation of the satellite derived gravity data.

anomalies for the lower mantle were carried out. The gravity effect of density variations in the lower mantle is hardly visible in the observed gravity field since the last one is dominated by the crustal and upper mantle density heterogeneity (e.g., [13]). Another factor, which also hides the lower mantle effects, is the dynamic topography induced by mantle flow (e.g., [3] [12]). The effect of the dynamic topography is clearly visible in the residual isostatic anomalies computed for the Middle East and surrounding areas [13] [14]. It has been demonstrated above that using the specific data processing provides nevertheless an opportunity, to refine patterns related to the lower mantle (Figure 2). Another way is to refine the lower mantle gravity field by subtracting gravity effects of the crust and upper mantle based on independent models obtained from various kinds of seismic data constrained by mineral physics [13]. Here we demonstrate the results of this approach for the study area.

The procedure of computation of the residual gravity field consisted of two steps: 1) removing of the crustal gravity effect (including topography/bathymetry) from the observed gravity field, and 2) computation of the residual gravity anomalies for the lower mantle by removing the effect of the upper mantle from the total mantle field (the final map is shown in Figure 3).

In the first stage, a 3D density model of the crust has been constructed for the Middle East and surroundings based on nearly all available seismic and a large set of geophysical prospecting data. Based on this model, the gravity effect of the 
crust has been determined relative to a $1 \mathrm{D}$ reference density model and removed from the initial gravity field together with the effect of topography/bathymetry. Accordingly, the effect of the dynamic topography as a part of the observed one is also excluded from the initial field [13].

Reducing the gravity effect of the upper mantle was based on available tomography models. For this purposes we employed S-wave variations from the model SL2013sv [26]. For depths less than $300 \mathrm{~km}$, the density variations have been obtained based on the mineral physics approach [27]. Below, a constant conversion ratio $\partial(\ln \Delta \rho) / \partial(\ln \Delta V s)=0.28$ (where $\rho$ is the density, $V s$ is the velocity of shear waves) [28]. The gravity effect of the upper mantle with the transition zone (to a depth of $700 \mathrm{~km}$ ) has been calculated relative to a $1 \mathrm{D}$ reference model and removed from the whole mantle anomalies [29]; the final results are shown in Figure 3.

The most pronounced negative anomaly corresponds to the Afar triple junction (this tectonic feature is shown in Figure 4), while the northern part related to Eurasia and the Eurasia-Arabia transition zone is characterized mainly by significant positive anomalies.

The lower mantle gravity field was significantly modified compared to the whole mantle anomalies. For example, the effect of the Afar plume is almost reduced, while South Eurasia is now characterized by predominantly negative anomalies (Figure 3 ). The residual gravity field is clearly composed of large and

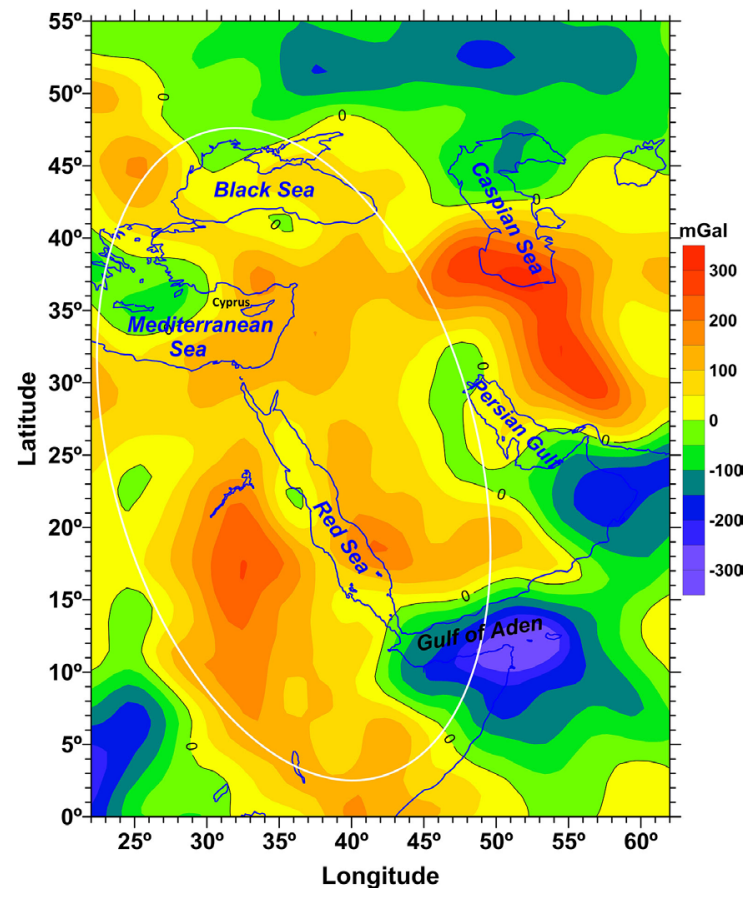

Figure 3. Residual gravity anomalies for the lower mantle after removing effect of the upper mantle (methodology is presented in [13]) from the total mantle field. The upper mantle gravity anomalies were computed based on the tomography model SL2013sv [26] as described in [29]. White ellipse shows approximate location of the maximum in Figure 2. 


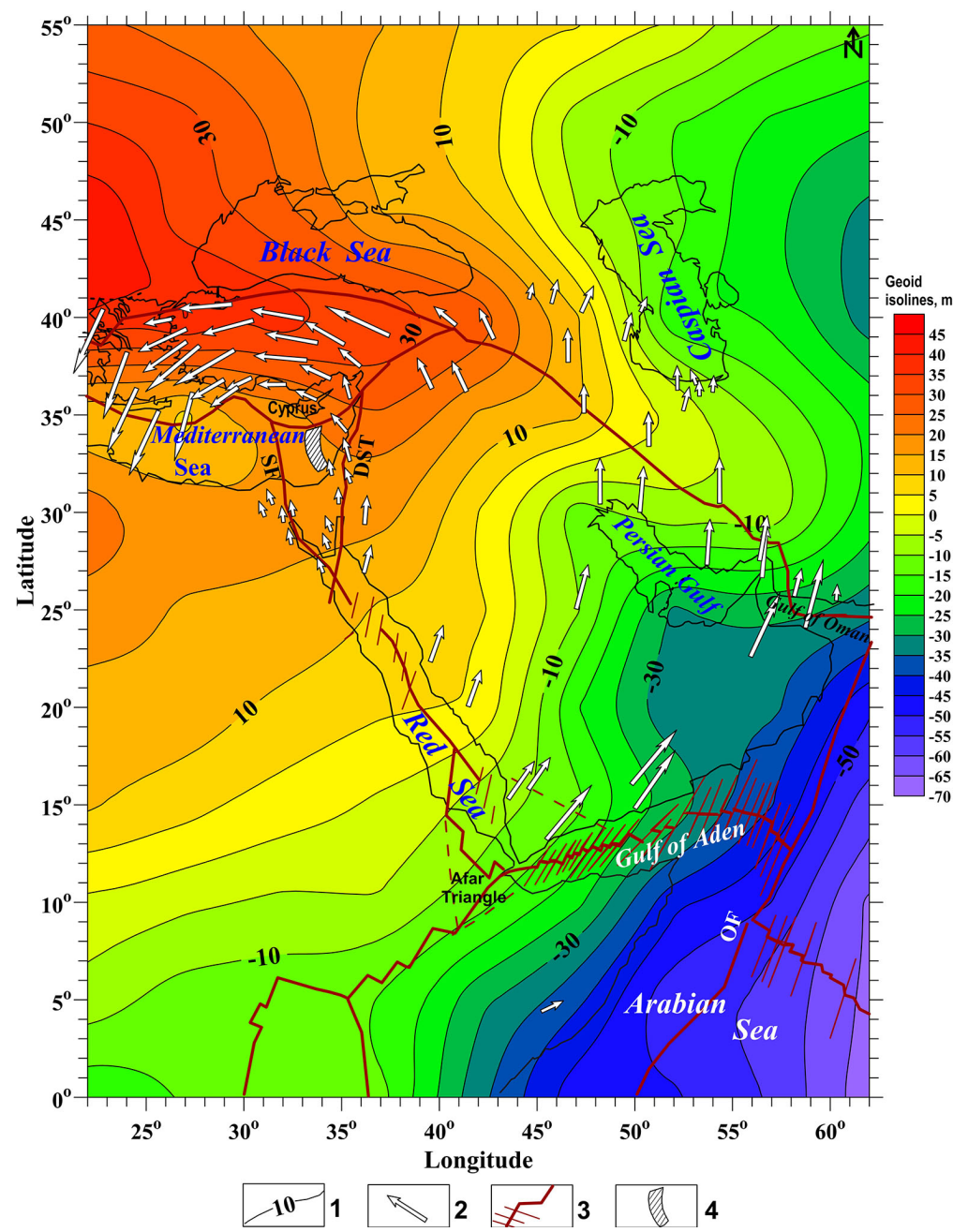

Figure 4. Map of geoid isolines (constructed on the basis of the EMG2008 (http://earth-info.nga.mil/...)) integrated with GPS velocities and main tectonic elements: 1) geoid isolines, 2) GPS velocity vectors [6] [19], 3) main intraplate faults, 4) Kiama paleomagnetic hyperzone of inverse polarity [30]. SF, Sinai Fault, DST, Dead Sea Transform, OF, Owen Fault.

mid-scale anomalies roughly dominated at the intervals $>1000 \mathrm{~km}$ and $<400 \mathrm{~km}$ correspondingly. The mid-scale anomalies cannot be generated by lower mantle heterogeneity due to a large distance to the original density anomalies. Obviously, they are related to insufficient resolution of the initial tomography model and uncertainties of the velocity-to-density conversion as demonstrated in [29]. We can select two groups of the large-scale positive residual anomalies. The first group combines the maxima in the Eastern Mediterranean and around the Red Sea (Figure 3). This broad anomaly fits well to the residual anomaly revealed by the numerical analysis of the initial field (Figure 2) as shown by the white ellipse. Therefore, this analysis also confirms the presence of the deep dense structure in the lower mantle in the study area. Another strong positive anomaly (right side of Figure 3) is localized within the collision zone of Arabia and Eurasia. 


\section{Brief Analysis of Geoid Data}

Generalized geoid isolines (compiled on the basis of the EMG2008) and their comparison with GPS data are shown in Figure 4. It is well known that the geoid map reflects integrated effects from the Earth's crust, mantle and core (e.g., [31]). Behavior of the geoid isolines (Figure 4) reflects a large quasi-circular anomaly nicely correlating with the GPS vectors orientation (see arrows in Figure 4). Interestingly that numerous paleomagnetic, tectonic-geodynamic data for the region under study also indicate mainly counterclockwise rotation.

In general, elevations of the geoid reflect the arch of the structure, and the lower one-periclinal part. Geodynamically this map agrees with the GPS data pattern. The geoid anomalies also correlate to a large extent with the regional tectonic elements presented in this figure. The geoid isolines show an elongated zone occurring from the NNE to SSW, which separates areas of positive and negative geoid values. These inhomogeneities in the Earth deep mantle have been previously interpreted as the planetary Ural-African Step [32]. At present, based on the GPS, paleomagnetic and seismic data analysis (see below) we propose that such a behavior of geoid isolines is caused by the integrated effect of the earlier recognized Ural-African Step and large anomalous source occurring at a great depth (GDRS).

\section{Integrated Analysis of Geophysical and Geological Factors}

Geodynamic analyses (e.g., [33]) indicate that arched segments of geological structures usually are the most non-stable zones (especially in the case of rotation). The Red Sea spreading zone is sharply outlined by an intensive trend of the Bouguer gravity anomalies [34] coinciding with the long axis of the residual satellite observed regional gravity anomaly (GDRSP's arched sector) (Figure 5) in center of which occurs the high-amplitude Cyprus Bouguer gravity anomaly [11].

The Red Sea zone contains also signatures of the deep geodynamic activity (e.g., [17] [49] [50] [51]). Thus, it provides an additional argument for the deep ring structure influence on the overlying slabs.

Figure 5 shows a simplified tectonic scheme of the region overlain on the gravity polynomial cubic surface approximation accompanied by rotational geodynamic elements. Elements of rotational dynamics (mainly obtained from paleomagnetic data analysis (Figure 5)) largely coincide with the counter clockwise rotation of the GDRSP derived from GPS data. In this context, it should be noted that Muttoni et al. [52] on the basis of a study of paleomagnetic data of the Triassic period suggested that the Neotethys Ocean spreading axis was rotated counterclockwise at that period.

Rotation of the deep structure and its connection with the GDRSP can be also confirmed paleobiogeographically. Late Jurassic shallow-water deposits of the Negev, Antilebanon, Northern and Southern Palmyrides terranes include coral biostroms with brachiopod and echinoid banks. The brachiopod fauna 


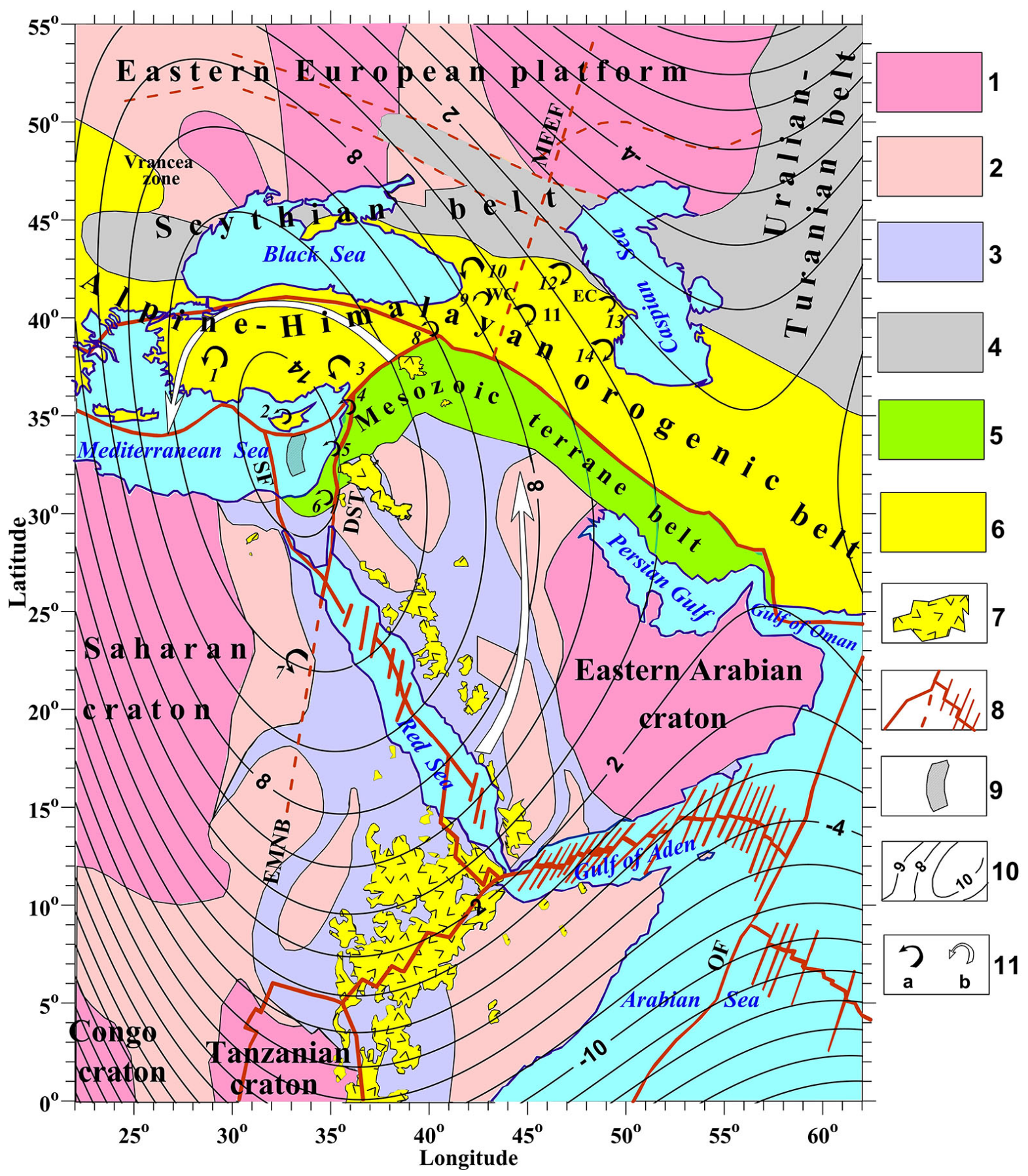

Figure 5. Simplified tectonic-geophysical scheme of the studied region overlaid on the gravity polynomial cubic surface approximation (see Figure 2) with rotational geodynamic elements. 1) Archean cratons, 2) Paleo-Middleproterozoic belts, 3) Neoproterozoic belt, 4) Late Paleozoic (Herzynian) belts, 5) Mesozoic terrane belt, 6) Alpine-Himalayan orogenic belt, 7) Cenozoic traps of African-Arabian rift belt, 8) main fault systems, 9) Kiama paleomagnetic hyperzone of inverse polarity [30] [35], 10) isolines of polynomial obtained regional gravity trend (see Figure 2), 11) rotational geodynamic elements derived from: a) paleomagnetic (major) and tectonic (minor) data: 1) Menderes (W. Anatolia) [36], 2) Cyprus [37], 3) E. Taurides [38] [39], 4) Lebanon [40], 5) Galilee magmatics and block systems [41], 6) dykes of Makhtesh Ramon (Negev terrane) [35], 7) Mansouri ring complex (SE Desert, Egypt) [42], 8) E. Pontides [43] [44], 9) Achara-Trialet belt [44] [45], 10) Rioni Basin [44] [46], 11) Sevan-Hakari zone (Lesser Caucasus) [45], 12) Dagestan [47], 13) Kur Depression [47] [48], 14) Nakhichevan and Talysh [44] [47]; b) GPS constructions [6] [19]. SF, Sinai Fault, DST, Dead Sea Transform, MEEF, Main Eastern European Fault, OF, Owen Fault, WC, Western Caucasus, EC, Eastern Caucasus. 
(Somalirhynchia-Septirhynchia) in these facies are very similar to those of the Ethiopian paleobiogeographical province in Saudi Arabia, Ethiopia, and Somalia [35]. Thus, the sedimentary deposits of the foreland of Northern Arabia and Eastern Nubia are tectonically discordantly joined with the allochthonic Mesozoic terrain belt (Figure 5) rotated towards the Gondwana counterclockwise.

The presence of the GDRS below the Eastern Mediterranean is also supported by independent deep seismic tomography [53]-[58] which indicate anomalous compressional and shear wave distributions at depths of $1000-1800 \mathrm{~km}$. Figure 6 (after [58]) displays a meridional seismic tomography section along the Antalya region (which occurs at the latitude of $40^{\circ}$ ). Here seismic tomography results clearly indicate a presence of a mantle occurring inhomogeneous anomalous source within the GDRS contour. It is necessary to note that a rotating circular (elliptical) inhomogeneous structure may produce very complex and diverse effects inside it [33], so here anomalous processes of different signs may simultaneously be observed.

Here $\mathbf{A}$ red line marks the location of the modern geological record that authors of [58] interpret to have formed during the subduction of the slab; B is location map of vertical cross-sections $\mathbf{C}$ (P-waves) and D (S-waves). Relative amplitude strength, vertical, lateral extent and dip trend are very similar between tomographic models.

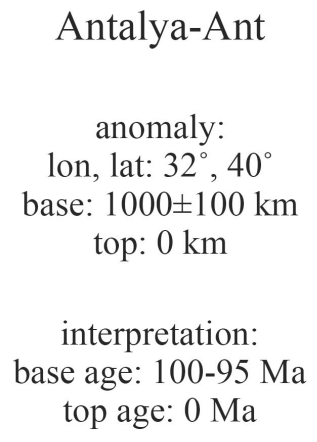

Antalya-Ant

anomaly:

lon, lat: $32^{\circ}, 40^{\circ}$

base: $1000 \pm 100 \mathrm{~km}$

top: $0 \mathrm{~km}$

interpretation:

base age: $100-95 \mathrm{Ma}$

top age: $0 \mathrm{Ma}$
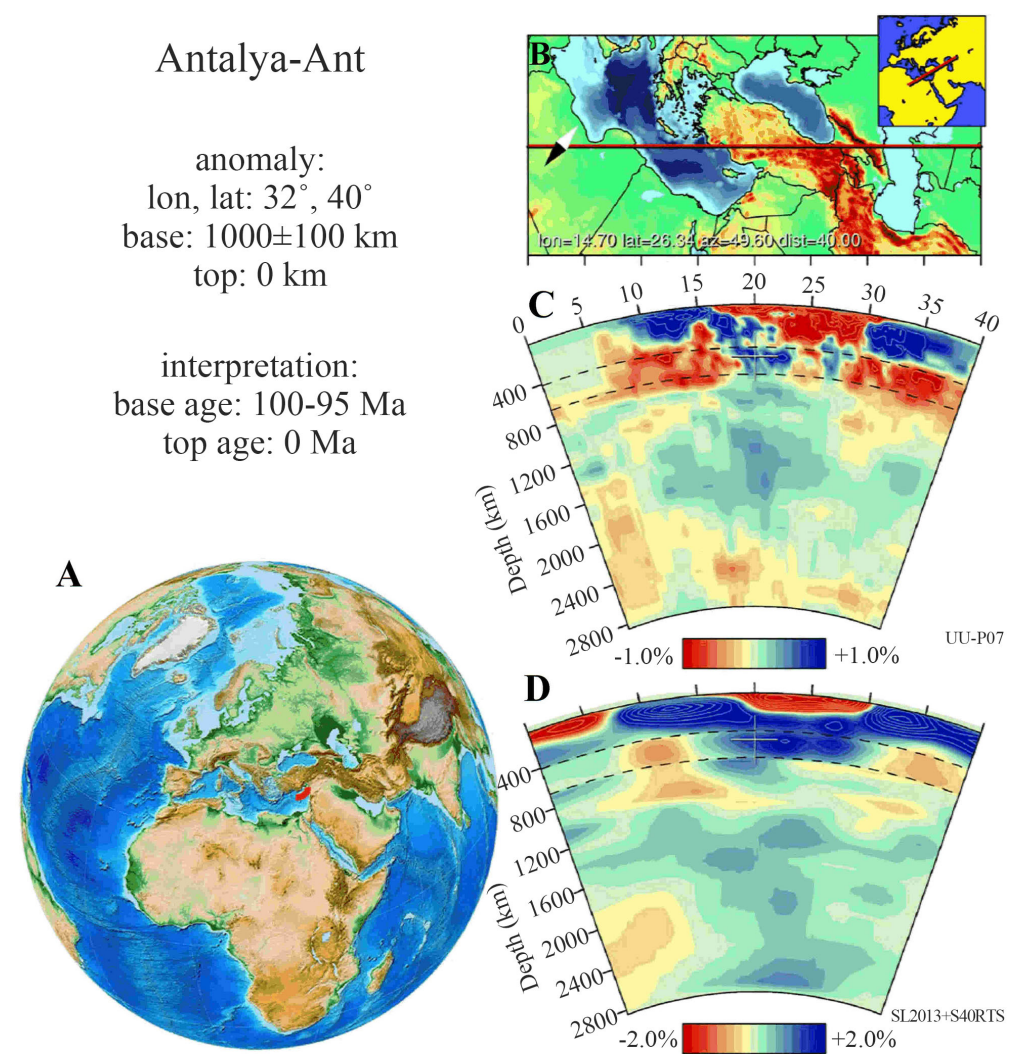

Figure 6. Antalya seismic tomography anomaly (after [58]), with small simplifications. 
The center of the GDRSP is also associated with low regional heat flow anomalies ( $\left.15-30 \mathrm{~mW} / \mathrm{m}^{2}\right)$ [35] [59] [60] which we consider an expression of the thermal mature age of the lithosphere in the region. An uniqueness of this zone underlines a fact that the probably oldest block of the oceanic crust, the Kiama paleomagnetic hyperzone of inverse polarity (Late Carboniferous - Early Permian) with an upper edge occurring at about $10-11 \mathrm{~km}$ was found a few tens of $\mathrm{km}$ to the south of Cyprus [35] [61] (Figure 5 and Figure 7). The initial spreading of the Kiama hyperzone [35] apparently took place in the present Eastern Persian Gulf [39]; this tectonic unit may have been moved to its present location along the transform faults under the influence of the GDRSP. The Mesozoic terrane belt occurring within the GDRSP, has been rotated counter clockwise about 130 m.y. ago [35]. The rotation of the deep structure could contribute to the movement of the Kiama hyperzone oceanic block from the Persian Gulf (SE) to the eastern Mediterranean (NW).

The integrated geophysical-geodynamical-geological map presented in Figure 7 displays a number of geodynamic indicators: GPS pattern and abundant geological signatures-outcrops of deep magmatic elements (e.g., [35] [61] [62] [63] [64] [65]) and major tectonic features.

Outcrops of the various deep magmatic elements were recognized in Cyprus (e.g., [66] [92] [93]). This indicates a high level of tectono-geodynamic activity within the GDRSP. The GPS pattern [6] [19] displays the clear counter clockwise rotation in the central-western part of the region (Figure 7) similar to expected effects of rotation of the so-called geodynamical vortex structure (correlating with the gravity generalized trend shown in Figure 2) in the center on which the high-amplitude Cyprus gravity anomaly [11] is located.

The axis of separation of the Western Caucasus (WC) and Eastern Caucasus (EC) zones - the Main East European Fault (MEEF) (e.g., [94] [95]); at present the MEEF is considered as a system of faults) - continues to the North within the Eastern European platform (Figure 5 and Figure 7). This fault, however, does not continue to the southern analog of this structure, the Eastern Mediterranean Nubian Fault (EMNB) [16] [35] [65] (shifted relative to MEEF for 500 $600 \mathrm{~km}$ to the west), which is an axial fault of the GDRSP of the Mesozoic age (Figure 5 and Figure 7).

It should be noted that the MEEF divides the regions with predominantly counter clockwise (west) and clockwise (east) paleomagnetic rotation (Figure 5) as well as similar location of the GPS vectors (Figure 4).

Summarizing the analysis of the deep mineral-petrological and tectono-geodynamic indicators in the region (Figure 5 and Figure 7), we conclude:

1) The GDRSP is well marked by a variety of different magmatic features.

2) The largest occurrence of rocks and minerals of deep origin is concentrated in the GDRSP apical zone, in the center of which the Cyprus ophiolites are located; numerous deep mantle minerals were discovered in Cyprus (e.g., [66] [92]). 


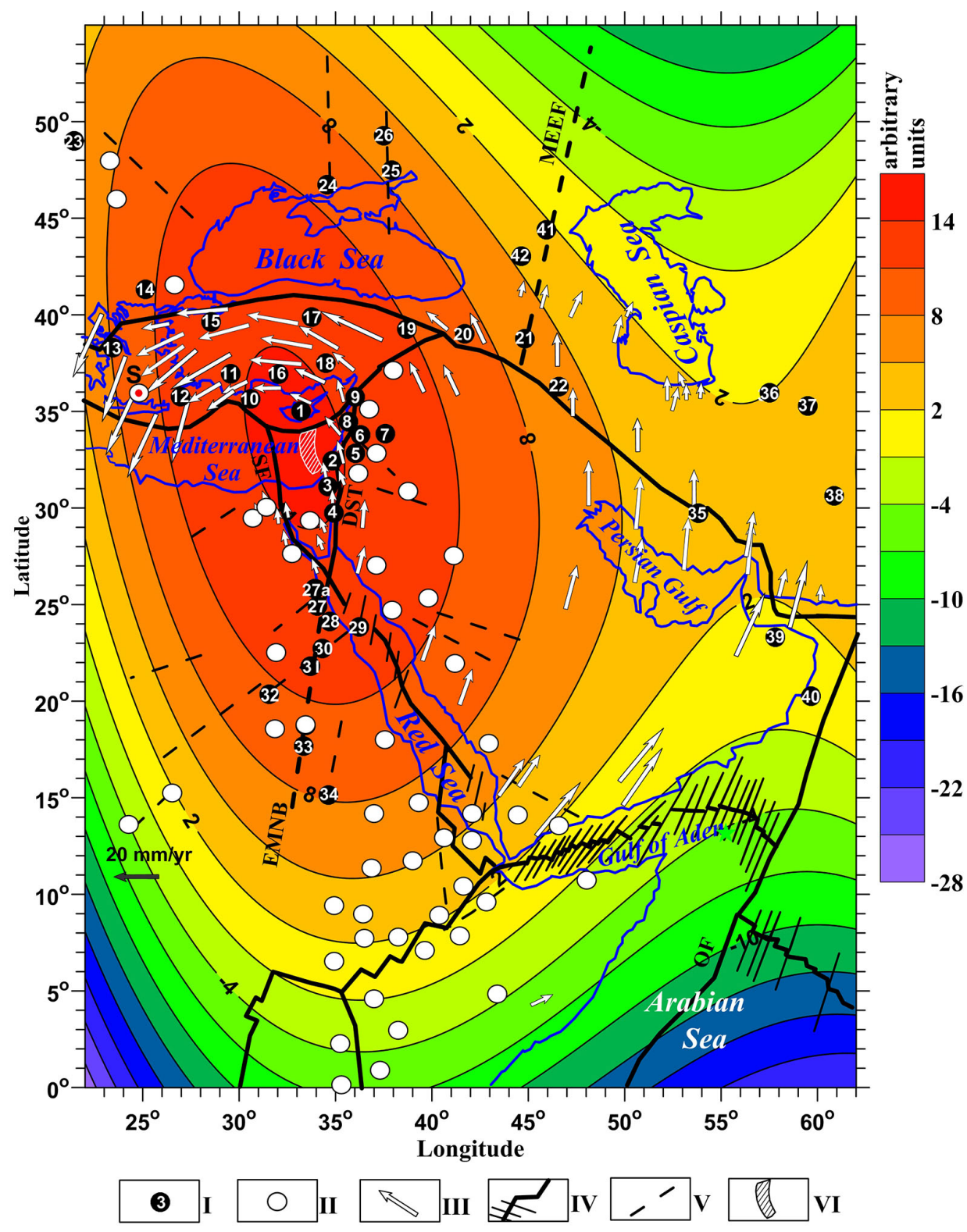

Figure 7. Integrated gravity-geodynamic-geological scheme of the hidden giant quasi-ring structure (applying the gravity polynomial approximation from Figure 2). (I) Main outcrops with the Mesozoic mantle rocks and minerals: 1) Cyprus [66] (Chan et al., 2008), 2) Mt. Carmel (N Israel), [63] [67], 3) Makhtesh Ramon (S Israel) [62], 4) Timna (S Israel) [68], 5) Jebel Sheqif (SW Syria) [69], 6) Nabi Matta (NW Syria) [70], 7) Jebel Rmah (S Syria) [69], 8) Baer-Bassit (NW Syria) [71], 9) Kizildag (S Turkey) [72], 10) Antalya (Turkey) [73], 11) Lycian (Turkey) [74], 12) Karphathos-Rhodes (S Greece) [75], 13) Locris-Beotia (Greece) [76], 14) Krumovgrad (S Bulgaria) [77], 15) Harmancik (NW Turkey) [78], 16) Beysehir (S Turkey) [79], 17) Ankara (Turkey) [80], 18) Pozanti-Korsanti (S Turkey) [81], 19) Tunceli (Turkey) [72], 20) Guleman (E Turkey) [72], 21) Khoy-Maku (NW Iran) [82], 22) Kermanshah-Kurdistan (NE Iraq-NW Iran) [82], 23) Sedlice (Slovakia) [83], 24) Sivash (S Ukraine) [84], 25) Priazov Massif (S Ukraine) [85], 26) Izium (E Ukraine) (data of the authors), 27) Abukhruq (SE Egypt) [86], a) Afia pipe, Wadi Zediun [65] (SE Egypt), 28) El Kahfa (SE Egypt) [87], 29) Zabargad Is. (Egypt) [88], 30) El Naga (SE Egypt) [87], 31) Mansouri (SE Egypt) [87], 32) Delgo (N Sudan) [89], 33) Wadi Shaq Um Bosh (E Sudan) [86], 34) Mindara (E Sudan) [86], 35) Neyriz (SE Iran) [82], 36) Sabzevar (Iran) [82], 37) Torbat-e-Haidarieh (Iran) [82], 38) Birjand-Nehbandan (E Iran) [82], 39) Semail (Oman) [82], 40) Masirah Is (Oman) [90], 41) Svetloyarskaya (SW Russia) [85], 42) Kuban traps [91] (N Caucasus, Russia). (II) Late Cenozoic traps and orogenic volcanic complexes, (III) GPS velocity vectors [6] [19], (IV) main interplate faults, (V) main intraplate (predominantly radial) faults, (VI) Kiama paleomagnetic hyperzone of inverse polarity [35]. SF, Sinai Fault, DST, Dead Sea Transform, MEEF, Main Eastern European Fault, OF, Owen Fault. 
3) The belt of Cenozoic traps along the line corresponding to the Red Sea strike [96] (Bosworth et al., 2005) agrees to the modern long axis of the GDRSP.

4) The ancient axis of the GDRSP is emphasized by EMNB and, possibly, by its northern extension-MEEF (Figure 5). The last fault divides the Caucasus Mts. into the Western and Eastern ones.

5) It is significant that both axes: ancient-Mesozoic (along EMNB) and modern-Cenozoic (along the Red Sea strike) were activated in the Late Cenozoic. They locate at an angle of $35^{\circ}-40^{\circ}$ each to other, and show the contours the western and eastern boundaries of the Sinai Plate originated at that time.

\section{Discussion}

The analysis of geodynamic and geological signatures included an examination of the deep magmatic element distribution including ophiolites, traps, large volcanic constructions and diatremes (Figure 7). The Mesozoic outcrops (caption I in Figure 7) indicate the location of rocks and minerals associated with mantle outflow (ophiolites, traps and mantle diapirs). The space distribution of these indicators shows a good correlation with both residual gravity anomaly and GPS pattern. Directions of deep radial faults (Figure 7) are oriented to the apical (arched) part of the GDRSP which is a supplementary geodynamic indicator of the deep structure impact on the near-surface.

The map of the generalized geoid isolines (Figure 4) presents a large quasi-circular anomaly which correlates well with the polynomial gravity anomalies (Figure 2), residual gravity anomalies computed for the lower mantle (Figure 3) and the GPS vector pattern (Figure 4 and Figure 5).

Analysis of paleomagnetic data (see Figure 5) indicates that the central part of the GDRSP corresponding to the following regions: Eastern Taurides, Turkey [38], Central Lebanon [40], Cyprus [37], Northern Israel [41], Southern Israel [35] and Eastern Egypt [42] is characterized by counter-clockwise rotation (in [41] the clockwise rotation was also observed). The Western Caucasus (WC) is associated with the peripheral part of the GDRSP mainly exhibiting counter-clockwise rotation (e.g., [43] [44] [46]), whereas the Eastern Caucasus (EC) (Figure 4) located outside the GDRSP, primarily presents a clockwise rotation (e.g., [44] [47] [48] [97]). Morris et al. [98] derived that the Cyprus (Troodos) and Syria (Baer Bassit) ophiolites underwent large counterclockwise rotations. These paleomagnetic data agree in general with the isoline shape of the gravity data polynomial approximation and the GPS global pattern.

The reconstruction of the axial position of the GDRSP at the boundary between Mesozoic and Cenozoic is a natural structural limitation of the Sinai plate, whose geodynamic unity has been amply documented [99]. The development of asymmetric basins along the continental transform faults over the eastern part of the GDRSP was studied by Ben-Avraham [100]. The asymmetric structure of these basins and their left regional counter-clockwise rotation may be interpreted as an obvious influence of the GDRSP. 
Suetsugu et al. [101], on the basis of seismic studies of the deep structure of the South Pacific, proposed a model of superplume from the lower mantle, which generates a series of small narrows plumes to subsurface. This model may correspond to our case with the giant lower mantle structure and high-intensive, but comparatively narrow Cyprus Bouguer gravity anomaly in its center (apparently produced by a small plume occurring at a relatively small depth).

A relationship between the rotation factors, middle latitudes and global geodynamics is emphasized in [102] [103]. A possible tectonic origin of the discovered structure (superplume?) may be linked to its critical $\cong 35^{\circ}$ latitude caused by variations in the Earth's rotation velocity and tidal forces [104] [105]. Obviously, these effects producing geoid pulsations can be accompanied by corresponding changes in the total planet's volume and, consequently, triggering deformations and stresses of the Earth. This phenomenon was predicted in the Véronnet theorem [106] indicating that at approximately the $35^{\circ}$ latitude a zone of the conjugate deformation of the Earth's ellipsoid could occur. It should be underlined that the center of the recognized deep structure practically coincides with the $35^{\circ}$ latitude (Figure 2, Figure 4, Figure 6, Figure 7).

The existence of the giant deep ring structure (GDRS) is supported by the following independent geophysical-geological features: 1) polynomial obtained ring (ellipsoidal) gravity trend, 2) computations of residual gravity anomalies from the lower mantle, 3) behavior of the ring counter clockwise GPS vector setting, 4) corresponding anomaly in the map of geoid isolines, 5) seismic tomography data, 6) paleomagnetic data indicating counter clockwise rotation, 7) mineralogical-petrological data indicating tectonic-geodynamic activity, 8) geodynamic conclusions about the conjugate deformation of the Earth's ellipsoid around the $35^{\circ}$ latitude, and 9) tectonic pattern. We have presented nine independent positive indicators (we consider only primary features) and random coincidence of these factors (e.g., [107]) is very small.

\section{Conclusions}

This study sheds light on the relationship between earlier unknown deep phenomena and near-surface geological-geophysical features. It appears that the presence of a deep rotating ring structure (superplume?) is reflected by several main independent indicators: satellite derived gravity data polynomial processing and computations of residual gravity anomalies for the lower mantle, results of seismic tomography, GPS data patterns, paleomagnetic data examination, behavior of geoid isolines, as well as evidence from the tectonic-structural, geodynamic, petrological and mineralogical data. Probabilistically, a random coincidence of all these factors is extremely small.

Obviously, the deep ring structure influencing many tectonic-geodynamical processes is a zone that may be a geodynamic factor contributing to the Red Sea spreading. We propose that this structure affects, for instance, geological-geophysical phenomena such as the high-amplitude Cyprus gravity anomaly, 
the Sinai plate configuration, counter clockwise rotation of the Mesozoic terrane belt, the geometry of asymmetrical basins along the Dead Sea Transform and the movement of the tectonic unit of the Kiama paleomagnetic zone.

\section{Acknowledgements}

The authors would like to thank Prof. Y. Rolland (University of Nice), who thoroughly reviewed the manuscript, and whose critical comments and valuable suggestions were helpful in preparing this paper.

\section{Conflicts of Interest}

The authors declare no conflicts of interest regarding the publication of this paper.

\section{References}

[1] Cloetingh, S. and Willet, S.D. (2013) Linking Deep Earth and Surface Processes. EOS, 94, 53-54. https://doi.org/10.1002/2013EO050002

[2] Cloetingh, S., Tibaldi, A., Dobrzhinetskaya, L., Matenco, L., Nader, F. and de Vries, B.V.W. (2018) From the Deep Earth to the Surface: A Multiscale Approach. Global and Planetary Change, 171, 1-322. https://doi.org/10.1016/j.gloplacha.2018.10.007

[3] Faccenna, C., Becker, T.W., Auer, L., Billi, A., Boschi, L., Brun, J.P., Capitanio, F.A., Funiciello, F., Horvàth, F., Jolivet, L., Piromallo, C., Royden, L., Rossetti, F. and Serpelloni, E. (2014) Mantle Dynamics in the Mediterranean. Review of Geophysics, 52, 283-332. https://doi.org/10.1002/2013RG000444

[4] Ben-Avraham, Z. and Ginzburg, A. (1990) Displaced Terranes and Crustal Evolution of the Levant and the Eastern Mediterranean. Tectonics, 9, 613-622. https://doi.org/10.1029/TC009i004p00613

[5] Muttoni, G., Kent, D.V., Garzanti, E., Brack, P., Abrahamsen, N. and Gaetani, M. (2003) Early Permian Pangea 'B' to Late Permian Pangea 'A'. Earth and Planetary Science Letters, 215, 379-394. https://doi.org/10.1016/S0012-821X(03)00452-7

[6] Reilinger, R.E., McClusky, S., Vernant, P., Lawrence, S., Ergintav, S., Cakmak, R., Ozener, H., Kadirov, F., Guliyev, I., et al. (2006) GPS Constraints on Continental Deformation in the Africa-Arabia-Eurasia Continental Collision Zone and Implications for the Dynamics of Plate Interactions. Journal of Geophysical Research, BO5411, 1-26. https://doi.org/10.1029/2005JB004051

[7] Stampfli, G.M., Hochard, C., Vérard, C., Wilhem, C. and von Raumer, J. (2013) The Formation of Pangea. Tectonophysics, 593, 1-19.

https://doi.org/10.1016/j.tecto.2013.02.037

[8] Rolland, Y., Hässig, M., Bosch, D., Bruguier, O., Melis, R., Galoyan, G., Topuz, G., Sahakyan, L., Avagyan, A. and Sosson, M. (2019) The East Anatolia-Lesser Caucasus Ophiolite: An Exceptional Case of Large-Scale Obduction, Synthesis of Data and Numerical Modelling. Geoscience Frontiers, 11, 83-108. https://doi.org/10.1016/j.gsf.2018.12.009

[9] Jolivet, L., Faccenna, C., Agard, P., de Lamotte, D.F., Menant, A., et al. (2016) Neo-Tethys Geodynamics and Mantle Convection: From Extension to Compression in Africa and a Conceptual Model for Obduction. Canadian Jour. of Earth Sciences, 53, 1-15. https://doi.org/10.1139/cjes-2015-0118

[10] Ben-Avraham, Z., Ginzburg, A., Makris, J. and Eppelbaum, L. (2002) Crustal Struc- 
ture of the Levant Basin, Eastern Mediterranean. Tectonophysics, 346, 23-43. https://doi.org/10.1016/S0040-1951(01)00226-8

[11] Gass, I.G. (1968) Is the Troodos Massif of Cyprus a Fragment of Mesozoic Ocean Floor? Nature, 220, 39-42. https://doi.org/10.1038/220039a0

[12] Boschi, L., Faccenna, C. and Becker, T.W. (2010) Mantle Structure and Dynamic Topographyin the Mediterranean Basin. Geophysical Research Letters, 37, L20303. https://doi.org/10.1029/2010GL045001

[13] Kaban, M.K., El Khrepy, S., Al-Arifi, N., Tesauro, M. and Stolk, W. (2016) Three Dimensional Density Model of the Upper Mantle in the Middle East: Interaction of Diverse Tectonic Processes. Journal of Geophysical Research: Solid Earth, 121, 5349-5364. https://doi.org/10.1002/2015JB012755

[14] Kaban, M.K., El Khrepy, S. and Al-Arifi, N. (2017) Importance of the Decompensative Correction of the Gravity Field for Study of the Upper Crust: Application to the Arabian Plate and Surroundings. Pure and Applied Geophysics, 174, 349-358. https://doi.org/10.1007/s00024-016-1382-0

[15] Eppelbaum, L.V. and Katz, Y.I. (2017) A New Regard on the Tectonic Map of the Arabian-African Region Inferred from the Satellite Gravity Analysis. Acta Geophysica, 65, 607-626. https://doi.org/10.1007/s11600-017-0057-2

[16] Eppelbaum, L., Katz, Yu., Klokochnik, J., Kosteletsky, J., Ben-Avraham, Z. and Zheludev, V. (2018) Tectonic Insights into the Arabian-African Region Inferred from a Comprehensive Examination of Satellite Gravity Big Data. Global and Planetary Change, 171, 65-87. https://doi.org/10.1016/j.gloplacha.2017.10.011

[17] Eppelbaum, L.V. and Katz, Y.I. (2020) Significant Tectono-Geophysical Features of the African-Arabian Tectonic Region: An Overview. Geotectonics, 54, 266-283.

[18] Sandwell, D.T., Garcia, E., Soofi, K., Wessel, P. and Smith, W.H.F. (2013) Toward 1 $\mathrm{mGal}$ Global Marine Gravity from CryoSat-2, Envisat, and Jason-1. The Leading Edge, 32, 892-899. https://doi.org/10.1190/tle32080892.1

[19] Doubre, C., Déprez, A., Masson, F., Socquet, A., Lewi, E., Grandin, R., Nercessian, A., Ulrich, P., De Chabalier, J.-B., Saad, I., Abayazid, A., Peltzer, G., Delorme, A., Calasis, E. and Wright, T. (2017) Current Deformation in Central Afar and Triple Junction Kinematics Deduced from GPS and InSAR Measurements. Geophysical Journal International, 208, 936-953. https://doi.org/10.1093/gii/ggw434

[20] Ahlberg, J.H., Nilson, E.N. and Walsh, J.N. (1967) The Theory of Splines and Their Applications. Academic Press, London.

[21] Barbeau, E.J. (2003) Polynomials. Ser.: Problem Books in Mathematics, Springer, Berlin, Heidelberg.

[22] Lemoine, F.G., et al. (1996) The NASA and DMA Joint Geopotential Model. 1996 Eos, Transactions American Geophysical Union.

[23] Telford, W.M., Geldart, L.R. and Sheriff, R.E. (1990) Applied Geophysics. Cambridge University Press, Cambridge. https://doi.org/10.1017/CBO9781139167932

[24] Khesin, B.E., Alexeyev, V.V. and Eppelbaum, L.V. (1996) Interpretation of Geophysical Fields in Complicated Environments. Ser.: Modern Approaches in Geophysics, Kluwer Academic Publishers (Springer), Dordrecht, London. https://doi.org/10.1007/978-94-015-8613-9

[25] Eppelbaum, L.V. and Khesin, B.E. (2012) Geophysical Studies in the Caucasus. Springer, Heidelberg, London. https://doi.org/10.1007/978-3-540-76619-3

[26] Schaeffer, A.J. and Lebedev, S. (2013) Global Shear-Speed Structure of the Upper Mantle and Transition Zone. Geophysical Journal International, 194, 417-449. 
https://doi.org/10.1093/gii/ggt095

[27] Tesauro, M., Kaban, M.K., Mooney, W.D. and Cloetingh, S.A.P.L. (2014) Density, Temperature, and Composition of the North American Lithosphere-New Insights from a Joint Analysis of Seismic, Gravity, and Mineral Physics Data: 2. Thermal and Compositional Model of the Upper Mantle. Geochemistry, Geophysics, Geosystems, 15, 4808-4830. https://doi.org.10.1002/2014GC005484.

[28] Steinberger, B. and Calderwood, A.R. (2006) Models of Large-Scale Viscous Flow in the Earth's Mantle with Constraints from Mineral Physics and Surface Observations. Geophysical Journal International, 167, 1461-1481. https://doi.org/10.1111/j.1365-246X.2006.03131.x

[29] Kaban, M.K., Petrunin, A.G., El Khrepy, S. and Al-Arifi, N. (2018) Diverse Continental Subduction Scenarios along the Arabia-Eurasia Collision Zone. Geophysical Research Letters, 45, 6898-6906. https://doi.org/10.1029/2018GL078074

[30] Eppelbaum, L.V., Nikolaev, A.V. and Katz, Y.I. (2014) Space Location of the Kiama Paleomagnetic Hyperzone of Inverse Polarity in the Crust of the Eastern Mediterranean. Doklady Earth Sciences, 457, 710-714. https://doi.org/10.1134/S1028334X14080212

[31] Richards, M.A. and Hager, B.H. (1984) Geoid Anomalies in a Dynamic Earth. Journal of Geophysical Research, 89, 5987-6002. https://doi.org/10.1029/JB089iB07p05987

[32] Katz, Y.I. (1986) Cretaceous Thalassocratic Maxima and Planetary Movements of Hydrosphere. In: Naidin, D.P., Ed., Cretaceous Period. Paleogeography and Paleooceanology, Nauka, Moscow, 191-237. (In Russian)

[33] Aleinikov, A.L., Belikov, V.T. and Eppelbaum, L.V. (2001) Some Physical Foundations of Geodynamics. Kedem Printing-House, Tel Aviv, Israel (In Russian).

[34] Makris, J., Henke, C.H., Egloff, F. and Akamaluk, T. (1991) The Gravity Field of the Red Sea and East Africa. Tectonophysics, 198, 369-381.

https://doi.org/10.1016/0040-1951(91)90161-K

[35] Eppelbaum, L.V. and Katz, Y.I. (2015) Eastern Mediterranean: Combined Geological-Geophysical Zonation and Paleogeodynamics of the Mesozoic and Cenozoic Structural-Sedimentation Stages. Marine and Petroleum Geology, 65, 198-216. https://doi.org/10.1016/j.marpetgeo.2015.04.008

[36] Uzel, B., Langereis, C.G., Kaymakci, N., Sözbilir, H., Özkaymak, C. and Özkaptan, M. (2015) Paleomagnetic Evidence for an Inverse Rotation History of Western Anatolia during the Exhumation of Menderes Core Complex. Earth and Planetary Science Letters, 414, 108-125. https://doi.org/10.1016/j.epsl.2015.01.008

[37] Borradaile, G.J., Lagroix, F., Hamilton, T.D. and Trebilcock, D.A. (2010) Ophiolite Tectonics, Rock Magnetism and Paleomagnetism, Cyprus. Survey of Geophysics, 31, 285-359. https://doi.org/10.1007/s10712-009-9090-2

[38] Kissel, C., Laj, C., Poisson, A. and Görür, N. (2003) Paleomagnetic Reconstruction of the Cenozoic Evolution of the Eastern Mediterranean. Tectonophysics, 362, 199-217. https://doi.org/10.1016/S0040-1951(02)00638-8

[39] Menant, A., Jolivet, L. and Vrielynck, B. (2016) Kinematic Reconstructions and Magmatic Evolution Illuminating Crustal and Mantle Dynamics of the Eastern Mediterranean Region Since the Late Cretaceous. Tectonophysics, 675, 103-140. https://doi.org/10.1016/j.tecto.2016.03.007

[40] Henry, B., Homberg, C., Mroueh, M., Hamdan, W. and Higazi, F. (2010) Rotations in Lebanon Inferred from New Palaeomagnetic Data and Implications for the Evolution of the Dead Sea Transform System. Geological Society, London, Special Pub- 
lications, 341, 269-285. https://doi.org/10.1144/SP341.13

[41] Ron, H., Freund, R., Garfunkel, Z. and Nur, A. (1984) Block Rotation by Strike-Slip Faulting: Structural and Paleomagnetic Evidence. Journal of Geophysical Research, 89P, 6256-6270. https://doi.org/10.1029/JB089iB07p06256

[42] Lotfi, H.I. (2015) Early Cretaceous Counterclockwise Rotation of Northeast Africa within the Equatorial Zone: Paleomagnetic Study on Mansouri Ring Complex, Southeastern Desert, Egypt. NRIAG Journal of Astronomy and Geophysics, 4, 1-15. https://doi.org/10.1016/j.nrjag.2015.01.001

[43] Hisarli, Z.M. (2011) New Paleomagnetic Constraints on the Late Cretaceous and Early Cenozoic Tectonic History of the Eastern Pontides. Journal of Geodynamics, 52, 114-128. https://doi.org/10.1016/j.jog.2010.12.004

[44] Rolland, Y. (2017) Caucasus Collisional History: Review of Data from East Anatolia to West Iran. Gondwana Research, 49, 130-146. https://doi.org/10.1016/j.gr.2017.05.005

[45] Meijers, M.J.M., Smith, B., Pastor-Gala, D., Degenaar, R. Sadradze, N., Adamia, S., Sahakyan, L., Avagyan, A., Sosson, M., Rolland, Y., Langereis, C.G. and Müller, C. (2015) Progressive Orocline Formation in the Eastern Pontides-Lesser Caucasus. In: Sosson, M., Stephenson, R.A. and Adamia, S.A., Eds., Tectonic Evolution of the Eastern Black Sea and Caucasus, Volume 428, Geological Society, Special Publications, London, 117-143. https://doi.org/10.1144/SP428.8

[46] Bazhenov, M.L. and Burtman, V.S. (2002) Eocene Paleomagnetism of the Caucasus (Southwest Georgia): Oroclinal Bending in the Arabian Syntaxis. Tectonophysics, 344, 247-259. https://doi.org/10.1016/S0040-1951(01)00189-5

[47] Halafly, A.A. (2006) Paleomagnetism of the Lesser Caucasus. Baku, Azerbaijan (In Russian).

[48] Ismailzadeh, T.A. (1983) Paleomagnetic Investigations of the Meso-Cenozoic Rocks of Azerbaijan. Institute of the Physics of the Earth, Moscow. (In Russian)

[49] Vannucci, G., Pondrelli, S., Argnani, S., Morelli, A., Gasperini, P. and Boschi, E. (2004) An Atlas Ozaref Mediterranean Seismicity. Annals of Geophysics, 47, 247-306.

[50] Zare, M., Amini, H., Yazdi, P., Sesetyan, K., Demircioglu, M.B., Kalafat, D., Erdik, M., Giardini, D., Khan M.A. and Tsereteli, N. (2014) Recent Developments of the Middle East Catalog. Journal of Seismology, 18, 749-772. https://doi.org/10.1007/s10950-014-9444-1

[51] El-Quliti, S.A., Al-Harbi, T.B.S., Al-Yami, M.B.S., Al-Ghamdi, A.B.M. and Al-Shammari, M.B.M. (2016) Assessment of Main Parameters of Extreme Earthquakes in Red Sea, West Coast of Saudi Arabia. Open Journal of Earthquake Research, 5, 122-134. https://doi.org/10.4236/ojer.2016.52010

[52] Muttoni, G., Erba, E., Kent, D.V. and Bachtadse, V. (2005) Mesozoic Alpine Facies Deposition as a Result of Past Latitudinal Plate Motion. Letters to Nature, 434, 59-63. https://doi.org/10.1038/nature03378

[53] Su, W.-J., Woodward, R.L. and Dziewonski, A.M. (1994) Degree-12 Model of Shear Velocity Heterogeneity in the Mantle. Journal of Geophysical Research, 99, 4945-4980. https://doi.org/10.1029/93JB03408

[54] Van der Hilst, R.D., Widiyantoro, S. and Engdahl, E.R. (1997) Evidence for Deep Mantle Circulation from Global Tomography. Nature, 386, 578-584. https://doi.org/10.1038/386578a0

[55] Wen L. and Helmberger, D.V. (1998) Ultra-Low Velocity Zones Near the Core-Mantle Boundary from Broadband PKP Precursors. Science, 279, 1701-1703. 
https://doi.org/10.1126/science.279.5357.1701

[56] Schmid, C., van der Lee, S., Van Decar, J.C., Engdah, E.R. and Giardin, D. (2008) Three-Dimensional S Velocity of the Mantle in the Africa-Eurasia Plate Boundary Region from Phase Arrival Times and Regional Waveforms. Journal of Geophysical Research, 113, B03306. https://doi.org/10.1029/2005JB004193

[57] Van der Meer, D.G., Spakman, W., van Hinsbergen, D.J.J., Amaru, M.L. and Torsvik, T.H. (2009) Towards Absolute Plate Motions Constrained by Lower-Mantle Slab Remnants. Nature Geoscience, 3, 36-46.

https://doi.org/10.1038/ngeo708

[58] Van der Meer, D.G., van Hinsbergen, D.J.J. and Spakman, W. (2018) Atlas of the Underworld: Slab Remnants in the Mantle, Their Sinking History, and a New Outlook on Lower Mantle Viscosity. Tectonophysics, 723, 309-448. https://doi.org/10.1016/j.tecto.2017.10.004

[59] Artemieva, I., Thybo, H. and Kaban, M.K. (2006) Deep Europe Today: Geophysical Synthesis of the Upper Mantle Structure and Lithospheric Processes over 3.5 Ga. In: Gee, D. and Stephenson, R., Eds., Special Volume "European Lithosphere Dynamics”, Volume 32, Geological Society of London, London, 11-41. https://doi.org/10.1144/GSL.MEM.2006.032.01.02

[60] Elgabry, M.N., Panza, G.F., Badawy, A.A. and Ibrahim, M.K. (2013) Imaging a Relic of Complex Tectonics: The Lithosphere Asthenosphere Structure in the Eastern Mediterranean. Terra Nova, 25, 102-109. https://doi.org/10.1111/ter.12011

[61] Eppelbaum, L.V. and Katz, Y.I. (2015). Newly Developed Paleomagnetic Map of the Easternmost Mediterranean Unmasks Geodynamic History of this Region. Central European Journal of Geosciences (Open Geosciences), 7, 95-117. https://doi.org/10.1515/geo-2015-0008

[62] Eppelbaum, L.V., Vaksman, V.L., Kouznetsov, S.V., Sazonova, L.M., Smirnov, S.A., Surkov, A.V., Bezlepkin, B., Katz, Y., Korotaeva, N.N. and Belovitskaya, G. (2006) Discovering of Microdiamonds and Minerals-Satellites in Canyon Makhtesh Ramon (Negev Desert, Israel). Doklady Earth Sciences, 407, 202-204. https://doi.org/10.1134/S1028334X06020097

[63] Griffin, W.L., Gain, S.E.M., Adams, D.T., Huang, J.-X., Saunders, M., Toledo, V., Pearson N.J. and O'Reilly, S.Y. (2016) First Terrestrial Occurrence of Tistarite $\left(\mathrm{Ti}_{2} \mathrm{O}_{3}\right)$ : Ultra-Low Oxygen Fugacity in the Upper Mantle beneath Mount Carmel, Israel. Geology, 44, 815-818. https://doi.org/10.1130/G37910.1

[64] Dobrzhinetskaya, L., Mukhin, P., Wang, Q., Wirth, R., O’Bannon, E., Zhao, W., Eppelbaum, L. and Sokhonchuk, T. (2018) Moissanite (SiC) with Metal-Silicide and Silicon Inclusions from Tuff of Israel: Search for a Primary Source. Lithos, 310-311, 355-368. https://doi.org/10.1016/j.lithos.2017.04.001

[65] Barakat, A.A. and Kandil, S.M.R. (2019) Diamond in the Newly Discovered Kimberlite and Related Rocks, Central Eastern Desert, Egypt. Proceedings of the XXXVI International Conference of "Magmatism of the Earth and Related Strategic Metal Deposits", St Petersburg University, Russia, 23-26 May 2019, 36-42.

[66] Chan, G.H.-N., Malpas, J., Xenopnontos, C. and Lo, C.-H. (2008) Magmatism Associated with Gondwanaland Rifting and Neo-Tethyan Oceanic Basin Development: Evidence from the Mamonia Complex, SW Cyprus. Journal of the Geological Society, 165, 699-709. https://doi.org/10.1144/0016-76492007-050

[67] Esperanza, S. and Garfunkel, Z. (1986) Ultramafic Xenoliths from the Mt Carmel Area (Karem Maharal Volcano), Israel. Lithos, 19, 43-49.

https://doi.org/10.1016/0024-4937(86)90014-9 
[68] Segev, A. (2000) Synchronous Magmatic Cycles during the Fragmentation of Gondwana: Radiometric Ages from the Levant and Other Provinces. Tectonophysics, 325, 257-277. https://doi.org/10.1016/S0040-1951(00)00122-0

[69] Krasheninnikov, V.A., Hall, J.K., Hirsch, F., Benjamini, H. and Flexer, A. (2005) Geological Framework of the Levant. Volume 1: Cyprus and Syria. Jerusalem, Israel.

[70] Sharkov, E.V. and Hanna, C. (1987) Evolution of the Upper Mantle Matter within the Regions of the Intraplate Basaltic Magmatism (on Example of the Western Syria). Doklady of the Academy of Sciences of the USSR, 297, 684-686.

[71] Roure, F., Casero, P. and Addoum, B. (2012) Alpine Inversion of the North African Margin and Delamination of Its Continental Lithosphere. Tectonics, 31, 1-28. https://doi.org/10.1029/2011TC002989

[72] Çimen, O., Toksoy-Köksal, F., Öztüfeksi-Önal, A. and Aktağ, A. (2016) Depleted to Refertilized Mantle Peridotites Hosting Chromitites within the Tunceli Ophiolite, Eastern Anatolia (Turkey): Insights on the Back Arc Origin. Ofioliti, 41, 1-20.

[73] Bagsi, U. (2013) The Geochemistry and Petrology of the Ophiolitic Rocks from the Kahramanmaraş Region, Southern Turkey. Turkish Journal of Earth Sciences, 22, 536-562.

[74] Akbulut, M., Colak, M., Oyman, T., Gnos, E. and Pişkin, O. (2009) Formation of Podiform Dunites in the Lycian Peridotite Nappes (Agla-Koycegiz, SW Turkey). Ofioliti, 34, 1-15.

[75] Dilek, Y. and Robinson, R.T. (2003) Ophiolites in Earth History. The Geological Society of America, Special Publication 218. https://doi.org/10.1144/GSL.SP.2003.218.01.01

[76] Pomonis, P. and Magganas, A. (2017) Petrogenetic Implications for Ophiolite Ultramafic Bodies from Lokris and Beotia (Central Greece) Based on Chemistry of Their Cr-Spinels. Geoisciences, 7, 1-16. https://doi.org/10.3390/geosciences7010010

[77] Dilek, Y. and Pavlides, S. (2006) Postcollisional Tectonics and Magmatism in the Mediterranean Region and Asia. The Geological Society of America, 409. https://doi.org/10.1130/SPE409

[78] Uysal, I., Şen, A.D., Ersoy, E.Y., Dilek, Y., Saka, S., Zaccarini, F., Escayola, M. and Karsl, O. (2014) Geochemical Make-up of Oceanic Peridotites from NW Turkey and the Multi-Stage Melting History of the Tethyan Upper Mantle. Mineral Petrology, 108, 49-69. https://doi.org/10.1007/s00710-013-0277-3

[79] Andrew, T. and Robertson, A.H.F. (2002) The Beysehir-Hoyran-Hadim Nappes: Genesis and Emplacement of Mesozoic Marginal and Oceanic Units of the Northern Neotethys in Southern Turkey. Journal of the Geological Society, 159, 529-543. https://doi.org/10.1144/0016-764901-157

[80] Şakir, Ü. and Üner, T. (2016) The Ankara Mélange: An Indicator of Tethyan Evolution of Anatolia. Geologica Carphatica, 67, 403-414. https://doi.org/10.1515/geoca-2016-0025

[81] Lian, D., Yang, J., Dilek, Y., Wu, W., Zhang, Z., Xiong, F., Liu, F. and Zhou, W. (2017) Deep Mantle Origin and Ultra-Reducing Conditions in Podiform Chromitite: Diamond, Moissanite, and Other Unusual Minerals in Podiform Chromitites from the Pozanti-Karsanti Ophiolite, Southern Turkey. American Mineralogist, 102, 1101-1113.

[82] Moghadam, H.S. and Stern, R.J. (2015) Ophiolites of Iran: Keys to Understanding the Tectonic Evolution of SW Asia: (II) Mesozoic Ophiolites. Journal of Asian Earth Sciences, 100, 31-59. https://doi.org/10.1016/j.jseaes.2014.12.016

[83] Koppa, M., Koller, F. and Putiš, M. (2014) Petrology and Geochemistry of a Perido- 
tite Body in Central-Carpathian Paleogene Sediments (Sedlice, Eastern Slovakia). Geologica Carphatica, 65, 387-399.

https://doi.org/10.2478/geoca-2014-0022

[84] Kazantsev, Y.V. (1982) Tectonics of the Crimea. Nauka, Moscow (In Russian).

[85] Alexandre, P. Chalot-Prat, F., Saintot, A., Wijbrans, J., Stephenson, R., Wilson, M., Kitchka, A. and Stovba, S. (2004) The 40Ar/39Ar Dating of Magmatic Activity in the Donbas Fold Belt and the Scythian Platform (Eastern European Craton). Tectonics, 23, TC5002. https://doi.org/10.1029/2003TC001582

[86] Wooley, A.R. (2001) Alkaline Rocks and Carbonatites of the World: Africa. Geological Society of London.

[87] Meneisy, M.Y. (1986) Mesozoic Igneous Activity in Egypt. Qatar University Science Journal, 6, 317-328.

[88] Bonatti, E., Ottonello, G. and Hamlyn, P.R. (1986) Peridotites from the Island of Zabargad (St. John), Red Sea: Petrology and Geochemistry. Journal of Geophysical Research, 91, 599-631. https://doi.org/10.1029/JB091iB01p00599

[89] Lucassen, F., Pudlo, D., Franz, G., Romer, R.L. and Dulski, P. (2013) Cenozoic Intra-Plate Magmatism in the Darfur Volcanic Province: Mantle Source, Phonolite-Trachyte Genesis and Relation to Other Volcanic Provinces in NE Africa. International Journal of Earth Sciences, 102, 183-205. https://doi.org/10.1007/s00531-012-0792-1

[90] Gnos, E. and Perrin, M. (1996) Formation and Evolution of the Masirah Ophiolite Constrained by Paleomagnetic Study of Volcanic Rocks. Tectonophysics, 253, 53-64. https://doi.org/10.1016/0040-1951(95)00056-9

[91] Rengarten, N.V and Starostina, Z.M. (1956) Geological-Lithological Investigations of Liasic Deposits in the Northern Slope of the Central Caucasus. In: Brizke, E.V., Ed., Geology and Useful Minerals of the Central Part of the Northern Caucasus, Academy of Sciences of the USSR, Moscow, 83-147.

[92] George Jr., R.P. (1978) Structural Petrology of the Olympus Ultramafic Complex in the Troodos Ophiolite, Cyprus. Geological Society of America Bulletin, 89, 845-865. https://doi.org/10.1130/0016-7606(1978)89<845:SPOTOU>2.0.CO;2

[93] Taylor, R.N. and Nesbitt, R.W. (1988) Light Rare-Earth Enrichment of Supra Subduction-Zone Mantle: Evidence from the Troodos Ophiolite, Cyprus. Geology, 16, 448-451. https://doi.org/10.1130/0091-7613(1988)016<0448:LREEOS >2.3.CO;2

[94] Shatsky, N.S. (1956) Tectonic Map of the USSR and Adjacent Countries. Scale: 1:5,000,000. Geosgeolizdat, Moscow.

[95] Kopp, M.L. (2004) Mobilistic Theory of Platforms of the South-Eastern Europe. Nauka, Moscow (In Russian).

[96] Bosworth, W., Huchon, P. and McClay, K. (2005) The Red Sea and Gulf of Aden Basins. Journal of African Earth Sciences, 43, 334-378. https://doi.org/10.1016/j.jafrearsci.2005.07.020

[97] Khramov, A.N. (1987) Paleomagnetology. Springer, Berlin. https://doi.org/10.1007/978-3-642-71750-5

[98] Morris, A., Erson, M.W., Robertson, A.H. and Al-Riyami, K. (2002) Extreme Tectonic Rotations within an Eastern Mediterranean Ophiolite (Baër-Bassit, Syria). Earth Planetary Science Letters, 202, 247-261. https://doi.org/10.1016/S0012-821X(02)00782-3

[99] Ben-Avraham, Z. (1978) The Structure and Tectonic Setting of the Levant Continental Margin, Eastern Mediterranean. Tectonophysics, 46, 313-331. https://doi.org/10.1016/0040-1951(78)90210-X 
[100] Ben-Avraham, Z. (1992) Development of Asymmetric Basins along Continental Transform Faults. Tectonophysics, 215, 209-220. https://doi.org/10.1016/0040-1951(92)90082-H

[101] Suetsugu, D., Isse, T., Tanaka, S., Obayashi, M., Shiobara, H., Sugioka, H., Kanazawa, T., Fukao, Y., Barruol, G. and Reymond, D. (2009) South Pacific Mantle Plumes Imaged by Seismic Observation on Islands and Seafloor. Geochemistry, Geophysics, Geosystems, 10, 1-18. https://doi.org/10.1029/2009GC002533

[102] Anderson, D.L. (2007) New Theory of the Earth. 2nd Edition, Cambridge University Press, Cambridge.

[103] Khain, V.E. and Koronovsky, N.V. (2007) Planet Earth from Core to Ionosphere. KDU, Moscow (In Russian).

[104] Levin, B.W., Sasorova, E.V. and Domanski, A.V. (2013) Features of "Critical Latitudes", Variations of Rotation and Seismicity of the Earth. Bulletin of the Far Eastern Branch of the Russian Academy of Sciences, 3, 3-8. (In Russian)

[105] Levin, B.W., Sasorova, E.V., Steblov, G.M., Domanski, A.V., Prytkov, A.S. and Tsyba, E.N. (2017) Variations of the Earth's Rotation Rate and Cyclic Processes in Geodynamics. Geodesy and Geodynamics, 8, 206-212. https://doi.org/10.1016/j.geog.2017.03.007

[106] Véronnet, A. (1912) Rotation de l'Ellipsoide Hétérogène et Figure Exacte de la Terre. Journal de Mathématiques Pures et Appliquées, 8, 331-463.

[107] Koralov, L. and Sinai, Y.G. (2007) Theory of Probability and Random Processes. 2nd Edition, Springer, Berlin-Heidelberg.

https://doi.org/10.1007/978-3-540-68829-7 